В.П. КУЗЬМІНА

Донбаська національна академія будівництва і архітектури, м. Краматорськ ORCID: 0000-0002-9171-4054

Я.В. ШЕЛЕСТ

Донбаська національна академія будівництва і архітектури, м. Краматорськ

\title{
УДОСКОНАЛЕННЯ ВИРОБНИЧИХ СТРУКТУР ПІДПРИЕМСТВ АВТОМОБІЛЬНОГО ТРАНСПОРТУ
}

У роботі проведено аналіз сучасного стану ринку автотранспорту в Украйні станом на перший квартал 2021 року. Доведено необхідність та доиільність розвитку та удосконалення підприємств 3 обслуговування автомобілів в цілому, підвищення їх подальшої ефективності та конкурентоспроможності. Проаналізовано методи, прочедури визначення стану, рівень та порядок розробки програм і планів розвитку виробничої структури підприємства автомобільного транспорту та ї̈ складових частин. Наведено методологію початкового проєктування виробничих структур підприємства, перелічено важливі напрямки розвитку виробничої структури підприємств автосервісу. Представлено вимоги відповідності виробничої структури підприємства автомобільного транспорту для більи ефективної роботи. Наведено показники ефективності та гнучкості виробничого прочесу. Представлено систему аналізу складових виробничої структури, визначено показники оцінки ї̈ рівня та стану. Розроблено модель обтрунтування доцільності розширення виробничої структури. Критерієм доиільності розщирення повинен бути економічний показник, який враховує додаткові витрати на розширення виробничої структури та додатковий прибуток від залучення нових споживачів, розширення номенклатури і обсягів послуг. Проведено аналіз застосування моделей та показників оиінки рівня виробничої структури підприємства.

Ключові слова: автомобілі, технічне обслуговування, ремонт, виробничий прочес, виробнича структура, критерії оцінки показників, підприємства автомобільного транспорту.

С.Н. МАСТЕПАН

Харьковский национальный автомобильно-дорожный университет ORCID: 0000-0002-0115-5237

В.С. КУЗЬМИН

Донбасская национальная академия строительства и архитектуры, г. Краматорск ORCID: 0000-0002-8928-3857

В.П. КУЗЬМИНА

Донбасская национальная академия строительства и архитектуры, г. Краматорск ORCID: 0000-0002-9171-4054

Я.В. ШЕЛЕСТ

Донбасская национальная академия строительства и архитектуры, г. Краматорск

\section{СОВЕРШЕНСТВОВАНИЕ ПРОИЗВОДСТВЕННЫХ СТРУКТУР ПРЕДПРИЯТИЙ АВТОМОБИЛЬНОГО ТРАНСПОРТА}

В работе проведен анализ современного состояния рынка автотранспорта в Украине на первый квартал 2021 года. Доказана необходимость и иелесообразность развития и усовершенствования предприятий по обслуживанию автомобилей в иелом, повышение их дальнейшей эффективности и конкурентоспособности. Проанализированы методы, процедуры определения состояния, уровни и порядок разработки программ и планов развития производственной структуры предприятия автомобильного транспорта и его составных частей. Приведена методология начального проектирования производственных структур предприятия, перечислены важные направления развития производственной структуры предприятий автосервиса. Представлены требования соответствия производственной структуры предприятия автомобильного транспорта для более эффрективной работы. Приведены показатели эффективности и гибкости производственного проиесса. Представлена система анализа составляющих производственной структуры, определень показатели 
оценки ее уровня и состояния. Разработана модель обоснования иелесообразности расширения производственной структуры. Критерием целесообразности расширения должен являться экономический показатель, учитывающий дополнительные затраты на расширение производственной структуры и дополнительную прибыль от привлечения новых потребителей, расширение номенклатуры и объемов услуг. Проведен анализ применения моделей и показателей оценки уровня производственной структуры предприятия.

Ключевые слова: автомобили, техническое обслуживание, ремонт, производственный процесс, производственная структура, критерии оиенки показателей, предприятия автомобильного транспорта.

S.M. MASTEPAN

Kharkiv National Automobile and Highway University ORCID: 0000-0002-0115-5237

V.S. KUZMIN

Donbas national academy of civil engineering and architecture, Kramatorsk ORCID: 0000-0002-8928-3857

V.P. KUZMINA

Donbas national academy of civil engineering and architecture, Kramatorsk ORCID: 0000-0002-9171-4054

Y.V. SHELEST

Donbas national academy of civil engineering and architecture, Kramatorsk

\section{IMPROVEMENT OF PRODUCTION STRUCTURES OF AUTOMOBILE TRANSPORT COMPANY}

The paper analyzes the current state of the motor transport market in Ukraine as of the first quarter of 2021. The necessity and expediency of development and improvement of car service enterprises in general, increase of their further efficiency and competitiveness are proved. The analysis of methods, procedures for determining the state, level and procedure for developing programs and plans for the development of the production structure of the road transport enterprise and its components is carried out. The methodology of initial design of production structures of the enterprise is given, the important directions of development of the production structure of car service enterprises are listed. The requirements of compliance of the production structure of the road transport enterprise for more efficient work are presented. Indicators of efficiency and flexibility of the production process are given. The system of analysis of the components of the production structure is presented, the indicators of assessment of its level and condition are determined. A model of substantiation of expediency of expansion of production structure is developed. The criterion for the feasibility of expansion should be an economic indicator that takes into account the additional costs of expanding the production structure and additional income from attracting new customers, expanding the range and scope of services. The analysis of application of models and indicators of an estimation of level of production structure of the enterprise is carried out.

Keywords: cars, automobiles, maintenance, repair, production process, production structure, criteria for evaluating indicators, road transport enterprises.

\section{Постановка проблеми}

Стан та рівень функціонування структури виробництва технічного обслуговування (ТО) та ремонту автомобілів на підприємствах автомобільного транспорту (ПАТ) є показниками необхідності розвитку та удосконалення підприємства в цілому, підвищення його подальшої ефективності та конкурентоспроможності. Методи розвитку, удосконалювання виробництва з обслуговування та ремонту автомобілів не завжди базуються на нових моделях, та методиках управління удосконаленням, розвитком виробничих структур підприємства. Не завжди проводиться вивчення ринку послуг і не враховується інформація про його стан.

На підприємствах важливим питанням є забезпечення підвищення ефективності використання виробничої потужності структурних підрозділів, оскільки витрати на виробничу базу в структурі собівартості послуг з обслуговування і ремонту автомобілів є значними. Необхідно приділяти увагу вдосконаленню виробничих структур, їх обгрунтованості та збалансованості.

\section{Аналіз останніх досліджень і публікацій}

Автомобільний транспорт в Україні розвивається, парк збільшується. За 1 квартал 2021 року було ввезено 125352 легкових автомобілів на загальну суму 920,9 млн дол., що на 8,4\% більше, ніж за аналогічний період 2020 року [1].

В довоєнний період автомобільний парк країни щорічно зростав на 5-7\%. Після початку війни темпи зростання набагато зменшилися. 
Сукупна вартість імпортованих нових авто зросла на $\$ 92,3$ млн, вживаних - на $\$ 6,1$ млн. Імпорт нових автомобілів в 1 кварталі 2021 у порівнянні з тим же періодом 2020 року зріс на 22,5\% [1].

Підприємствам необхідно враховувати поступовий перехід виробничого процесу в недалекому майбутньому на обслуговування значної частини електрокарів. Потрібно вже зараз створювати відповідну виробничу структуру.

Формування виробничих структур повинно проводитись за науково обгрунтованими планами та методиками. При цьому рекомендується проводити системний аналіз і використовувати підходи i методики проєктування виробничих структур на основі системного підходу [2].

\section{Формулювання мети дослідження}

Забезпечити підвищення ефективності виробництва з обслуговування та ремонту автомобілів на підприємствах автомобільного транспорту шляхом удосконалення виробничої структури.

\section{Викладення основного матеріалу дослідження}

В основі методології початкового проєктування виробничих структур підприємства та подальшого їх розвитку, удосконалення повинен використовуватись принцип системності: визначення системи цілей, потім розробка механізму досягнення загальної для виробництва та локальних цілей для складових частин виробничої структури.

При побудові виробничої структури необхідно використовувати наукові методи організаційного проектування, власний досвід, досліджувати і аналізувати діяльність кращих підприємств галузі, використовувати аналогічні схеми закордонних підприємств. В розумних межах можна використовувати інтуїцію.

Важливими напрямками розвитку виробничої структури підприємств в зв'язку з погіршенням клімату на землі $\epsilon$ створення можливості зменшення негативного впливу на екологію. Для цього необхідно забезпечити такі дії та заходи по розвитку виробничої структури $[3,4]$ :

- розробка на підприємствах заходів по захисту навколишнього середовища та відповідних елементів виробничих структур;

- створення виробничою структурою технічних та організаційних умов впровадження екологічно безпечних технологій технічного обслуговування і ремонту автомобілів;

- розробка на підприємствах заходів щодо скорочення викидів, відходів виробничою структурою в цілому та окремими ії підрозділами;

- забезпечення адекватності техніко-технологічного стану виробничої структури обслуговування і ремонту підприємства рівневі екологічності автомобілів, що обслуговуються; відходів.

- проектування складових загальної виробничої структури для утилізації власних виробничих

Програма та плани розвитку виробничої структури підприємства повинна будуватись на основі

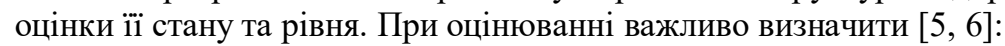

- відповідність розвитку виробничої структури підприємства ринку послуг в даному регіоні;

- наявність просторового та структурного потенціалу на підприємстві для можливого розширення виробництва відповідно до динаміки змін ринку послуг;

- відповідність технічного обслуговування та ремонту вимогам до технологій та сервісним книжкам на автомобілі; технологій;

- своєчасність впровадження у виробництво новітнього технологічного устаткування i

- рівень організації на підприємстві залучення виконавців виробничого процесу до його розвитку, організації випробувань, експериментів, наукових досліджень процесів виробництва послуг $з$ обслуговування та ремонту автомобілів.

Для оцінки ефективності функціонування виробничої структури при визначенні необхідності та величини її оновлення доцільно використовувати відношення вихідних ресурсів процессу до вхідних [7]:

$$
E=\frac{D_{o p}}{B_{m t}},
$$

де $\quad D_{o p}-$ доходи підприємства від виконання послуг з технічного обслуговування та ремонту

автомобілів;

$B_{m t}-$ матеріальні, трудові витрати на проведення робіт по виробництву послуг.

Ефективність виробничого процесу ПАТ при розвитку його виробничої структури суттєво залежить від її гнучкості.

Аналіз показників ефективності та гнучкості виробничого процесу підприємства автомобільного транспорту представлено на рис. 1. 


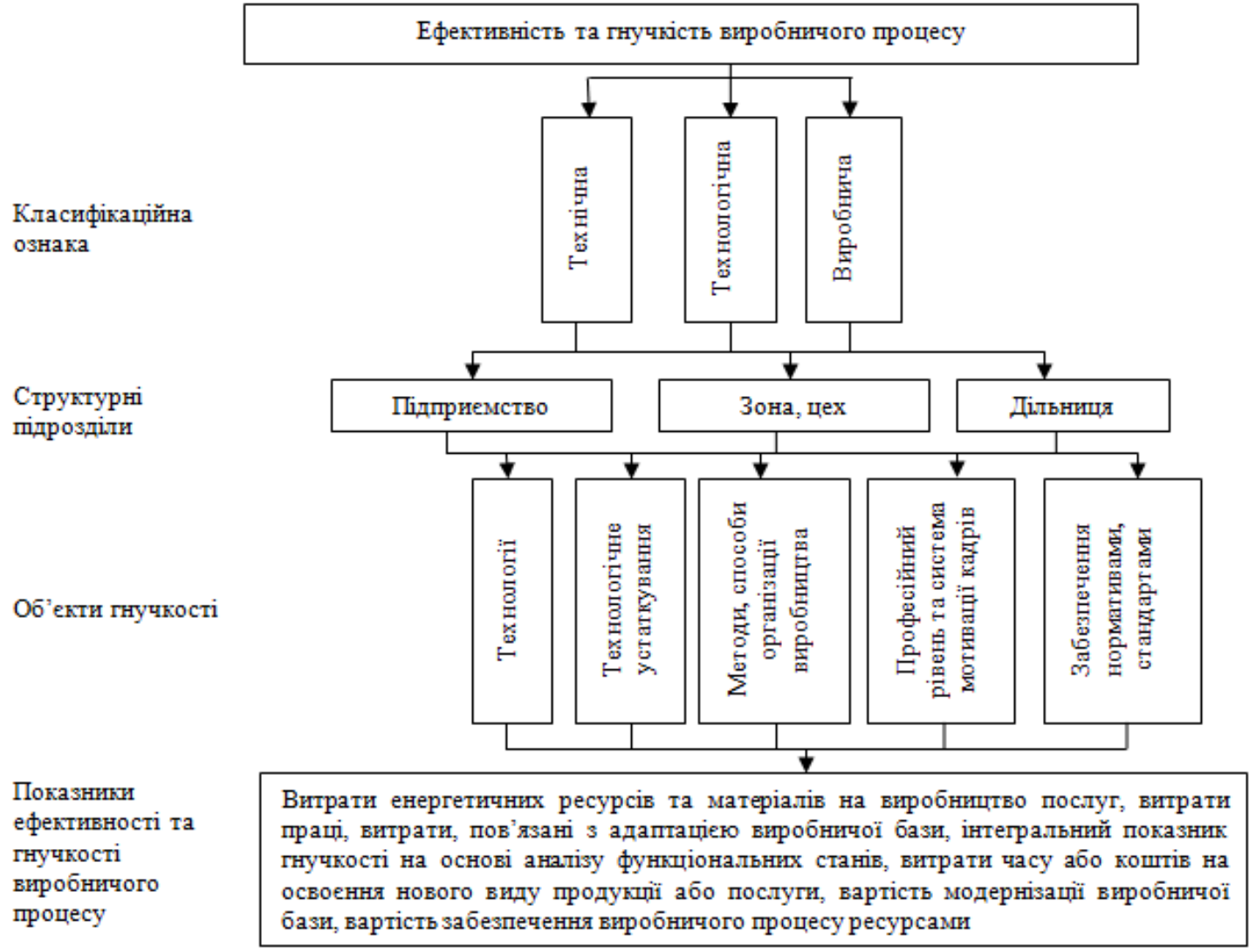

Рис. 1. Показники ефективності та гнучкості виробничого процесу

Гнучкість процесу це спроможність адаптувати процес, тобто пристосованість до змін умов, що відбуваються за зовнішніми і внутрішніми причинами відносно даного підприємства $[2,8,9]$.

Проблема удосконалювання, розвитку виробничої структури актуальні для підприємства завжди. Відбувається постійно оновлення рухомого складу транспорту, змінюються технології, організація праці.

Сучасна тенденція у формуванні або вдосконаленні виробничої структури полягає в тому, щоб зробити структуру відповідною новітнім технологіям, конструкції автомобілів.

Ефективна виробнича структура підприємства автомобільного транспорту повинна відповідати таким вимогам $[3,5]$ : автомобілів;

- забезпечувати виробництво якісних послуг 3 технічного обслуговування та ремонту

- відповідати потребам ринку послуг з обслуговування та ремонту автомобілів даного регіону;

- бути прийнятною організаційно та керованою, відповідати потребам i можливостям виробництва;

- мати раціональний розподіл задач, завдань виробництва і забезпечувати взаємозв'язки між структурними підрозділами;

- забезпечувати функціонування технологічних процесів обслуговування та ремонту, використовуючи екологічно безпечні, не шкідливі технології;

- бути економічно ефективною.

Критерієм обгрунтування доцільності розширення виробничої структури повинен бути економічний показник, який би враховував додаткові витрати на ії розширення та додатковий прибуток від залучення нових споживачів, розширення номенклатури і обсягів послуг.

Таким критерієм економічного напрямку може бути коефіцієнт змін питомих витрат на технічне обслуговування та ремонт автомобілів до розширення та 3 урахуванням можливого розширення виробничої структури підприємства. Функцію можна записати таким чином:

$$
K_{r w}=\frac{C_{d r}}{c_{r}},
$$

де $\quad K_{r w}-$ коефіцієнт змін витрат на виробництво одиниці послуги з обслуговування та ремонту автомобілів при розширенні виробничої структури; 
$C_{d r}-$ питомі витрати на виробництво одиниці послуги з обслуговування та ремонту автомобілів до розширення виробництва;

$C_{r}$ - питомі витрати на виробництво одиниці послуги з обслуговування та ремонту автомобілів після розширення виробництва.

Питомі витрати на виробництво одиниці послуги з технічного обслуговування та ремонту автомобілів на підприємстві до розширення виробництва визначаються за формулою:

$$
C_{d r}=\frac{B_{w p}}{o_{p d}},
$$

де $\quad B_{w p}-$ витрати на виробництво послуг до розширення виробничої структури підприємства грн.;

$O_{p d}$ - обсяг послуг з обслуговування та ремонту до розширення виробничої структури, люд. год.

Питомі витрати на виробництво одиниці послуги 3 технічного обслуговування та ремонту автомобілів після розширення виробництва підприємства можна визначити за формулою:

$$
C_{r}=\frac{B_{w p}+B_{w u}+B_{w m}+B_{w p r}}{O_{p}},
$$

де $\quad B_{w p}, B_{w u}, B_{w m}, B_{w p r}-$ витрати, відповідно, на виробництво послуг після розширення виробничої

структури підприємства, витрати на оснащення додаткової потужності виробничої структури

технологічним устаткуванням та оснащенням, витрати на матеріали для виробництва додаткових обсягів послуг, витрати на залучення додатково робітників, грн.;

$O_{p}$ - обсяг виробництва послуг після розширення виробничої структури підприємства, люд.год.

Розширення виробничої структури підприємства для збільшення номенклатури послуг, залучення додаткових споживачів i, відповідно, збільшення обсягів виробництва доцільне в тому випадку, коли коефіцієнт змін витрат на виробництво одиниці послуги $K_{r w}$ більше одиниці. Іншими словами: коли собівартість виробництва одиниці послуги при розширенні виробництва знижується.

\section{Висновки}

1. При формуванні напрямків розвитку виробничої структури підприємства автомобільного транспорту необхідно врахувати зовнішне та внутрішне середовища, від стану яких залежить можливість, напрямки та масштаби розвитку виробництва послуг з технічного обслуговування та ремонту автомобілів. підприємства.

2. Проведено аналіз застосування моделей та показників оцінки рівня виробничої структури

\section{Список використаної літератури}

1. Імпорт легкових авто у першому кварталі 2021 року: тенденції та індикатори ринку. [Електронний ресурс] - Режим доступу до статті: https://eauto.org.ua/news/19-import-legkovih-avto-u-1kvartali-2021-roku-tendenciji-ta-indikatori.

2. Всеобщее управление качеством: Учебник для вузов / О. П. Глудкин, Н. М. Горбунов, А. И. Гуров, Ю. В. Зорин. Под ред. О. П. Глудкина. - М.: Радио и связь, 1999. - 600 с.

3. Российская автотранспортная энциклопедия. Техническая эксплуатация, обслуживание и ремонт автотранспортных средств.» Том 3. - М.: Моск. автом.-дорожн. ин-тут, 2000. - 455 с.

4. Канарчук В. Є., Курніков І. П. «Виробничі системи на транспорті»: Підручник. - К.: Вища школа, 1997. -359 с.

5. Управление автосервисом: Учебное пособие для вузов / Под общ. ред. проф. Л. Б. Миротина. - М.: Издательство “Экзамен”, 2004. - 320 с.

6. Андрусенко С. I., Лобода А. В., Бугайчук О. С. Дослідження виробничої системи підприємства автосервісу з використанням її імітаційної моделі. //Вісник НТУ: В 2-х частинах: Ч.2. - К.: НТУ, 2007. - Випуск 15. - С. $10-17$.

7. Лукинский В. С. Модели и методы теории логистики: Учебное пособие. 2-е изд. - СПб.: Питер, 2007. - 448 с.

8. Федоркова Н. В. Направление достижения конкурентоспособности на основе повышения уровня гибкости / Н.В.Федоркова // Вестник ВГТУ. Научно-технический журнал. - Воронеж, 2001. Вып. 3.1. - С. $146-149$.

9. Бережна Е. В., Бережний В. И. Математичні методи моделювання економічних систем: Навч. посіб. - 2-е вид., перероб. і доп. - М.: Фінанси і статистика, 2006. - 432 с. 
1. Import of passenger cars in the first quarter of 2021: trends and indicators of the market. [Electronic resource] - Access mode to statistics: https:/eauto.org.ua/news/19-import-legkovih-avto-u-1-kvartali-2021-rokutendenciji-ta-indikatori.

2. Total quality management: Textbook for universities / Gludkin O.P., Gorbunov N. M., Gurov A. I., Zorin Yu. V., Ed. Gludkina O. P. Moscow: Radio and communication, 1999. 600 p.

3. Russian automobile transport encyclopedia. Technical operation, maintenance and repair of vehicles. Volume 3. Moscow. 200. 455 p.

4. Kanarchuk V.Y., Kurnikov I.P. Virobnichi systems on transport. Kiev: Vischa school, 1997. 359 p.

5. Car service management: Textbook for universities / Under total. ed. prof. L.B. Mirotina. Moscow Publishing house "Examination", 2004. 320 p.

6. Andrusenko S. I., Loboda A.V., Bugaychuk O. S. Doslidzhennya vyrobnychoyi systemy pidpryyemstva avtoservisu z vykorystannyam yiyi imitatsiynoyi modeli [Research of the production system of a car service enterprise using its simulation model]. Bulletin of NTU: In 2 parts: Part 2. Kyiv. NTU, 2007. Vipusk 15. P. 10 17.

7. Lukinsky V. S. Models and methods of the theory of logistics. St.Peterburh: Peter, 2007. 448 p.

8. Fedorkova N. V. The direction of achieving competitiveness on the basis of increasing the level of flexibility / N.V. Fedorkova // Vestnik VSTU. Scientific and technical journal. Voronezh, 2001. Issue. 3.1. P.146-149.

9. Berezhna E. V., Berezhny V. I. Mathematical methods for modeling economic systems. Moscow: Finance and statistics, 2006. 432 p. 